\title{
Functional electrical stimulation training on functional capacity and blood pressure variability in a centenarian woman: case study
}

\author{
Treinamento com estimulação elétrica funcional sobre a capacidade funcional e a \\ variabilidade da pressão arterial em uma idosa centenária: estudo de caso
}

Bruna Eibel', Graciele Sbruzzi', Thiago Dipp', Karina R. Casali', Rodrigo D. M. Plentz ${ }^{1,2}$

\begin{abstract}
Background: Functional electrical stimulation (FES) is a rehabilitation method that can revert alterations provoked by aging, such as reductions in functional capacity and modifications on blood pressure variability (BPV). Objectives: To evaluate the training effects of FES on functional capacity and BPV in a centenarian woman. Methods: A 101-year-old woman without previous disease underwent FES training for 12 weeks, with three 40 min sessions/week. FES was applied at a frequency of $20 \mathrm{~Hz}$ with a $0.5 \mathrm{~ms}$ pulse, $5 \mathrm{~s}$ contraction time, $10 \mathrm{~s}$ relaxation time, the maximum tolerable intensity and with progressive overload. Functional capacity was assessed with a six-minute walk test (6MWT) and proximal lower limb strength was assessed with a sit-and-stand test (STST). BPV was measured by continuous recording of pulse pressure and calculated by spectral analysis. All variables were measured before and after FES training. Results: After training there was a $70 \%$ increase in distance walked in the $6 \mathrm{MWT}$, a $300 \%$ increase in the number of STST repetitions, an $8 \mathrm{mmHg}$ reduction in systolic blood pressure (SBP) and a $4 \mathrm{mmHg}$ reduction in diastolic blood pressure (DBP) and mean blood pressure (MBP). Reductions in SBP $\left(11.8 \mathrm{mmHg}^{2}\right)$, DBP $\left(2.3 \mathrm{mmHg}^{2}\right)$ and $\mathrm{MBP}\left(6.0 \mathrm{mmHg}^{2}\right)$ variability were also observed. Conclusions: Three months of FES training improved functional capacity and BPV in a centenarian woman.
\end{abstract}

Keywords: electric stimulation; aged; autonomic nervous system.

\section{Resumo}

Contextualização: A estimulação elétrica funcional (EEF) é uma forma de reabilitação que pode reverter alterações provocadas pelo envelhecimento, como diminuição da capacidade funcional e modificações na variabilidade da pressão arterial (VPA). Objetivos: Avaliar os efeitos do treinamento com EEF sobre a capacidade funcional e a VPA em uma idosa centenária. Métodos: Paciente do sexo feminino, 101 anos e sem patologia prévia. O treinamento com EEF foi realizado durante 12 semanas, sendo três sessões/semana e tempo máximo de aplicação de $40 \mathrm{~min} / \mathrm{sessão.} \mathrm{A} \mathrm{EEF} \mathrm{foi} \mathrm{aplicada} \mathrm{com} \mathrm{frequência} \mathrm{de} 20 \mathrm{~Hz}$, largura de pulso de 0,5 ms, tempo de contração de $5 \mathrm{~s}$, tempo de repouso de $10 \mathrm{~s}$, intensidade máxima tolerável e aplicação de sobrecarga progressiva. A capacidade funcional foi avaliada por meio do teste de caminhada de 6 minutos (TC6) e do teste de sentar e levantar (TSL). A VPA foi mensurada pelo registro contínuo da pressão de pulso e calculada pela análise espectral. Todas as variáveis foram mensuradas pré e póstreinamento. Resultados: Após treinamento, houve um aumento de 70\% na distância percorrida no TC6 e aumento de 300\% no número de repetições no TSL. Observou-se redução de $8 \mathrm{mmHg}$ na pressão arterial sistólica (PAS) e de $4 \mathrm{mmHg}$ na pressão arterial diastólica (PAD) e na pressão arterial média (PAM), havendo ainda uma redução na variabilidade da PAS (11,8 mmHg $\left.{ }^{2}\right)$, da PAD (2,3 mmHg $\left.{ }^{2}\right)$ e da PAM $\left(6,0 \mathrm{mmHg}^{2}\right)$. Conclusões: O treinamento com EEF durante três meses proporcionou aumento da capacidade funcional e melhora da VPA em uma idosa centenária.

Palavras-chave: estimulação elétrica; idoso; sistema nervoso autônomo.

Received: 24/11/2010 - Revised: 17/04/2011 - Accepted: 19/04/2011

${ }^{1}$ Laboratory of Clinical Investigation, Instituto de Cardiologia do Rio Grande do Sul (IC), Fundação Universidade de Cardiologia (FUC), Porto Alegre, RS, Brazil ${ }^{2}$ Physical Therapy Department, Universidade Federal de Ciências da Saúde de Porto Alegre (UFCSPA), Porto Alegre, RS, Brazil Correspondence to: Rodrigo Della Méa Plentz, UFCSPA, Rua Sarmento Leite, 245, CEP 90050-170, Porto Alegre, RS, Brasil, e-mail: roplentz@yahoo.com.br 


\section{Introduction $: \therefore$.}

Brazil is experiencing a reversal in its population pyramid. The age group consisting of those over 65 years old increased from $3.5 \%$ in 1970 to $5.5 \%$ in 2000 and is expected to include about $19 \%$ of the national population in $2050^{1}$.

Functional capacity in this age group should be better clarified, thus allowing interventions that will result in improved functional performance and quality of life. Because muscle strength directly influences functional capacity in this population, the strengthening of the lower limb muscles plays a fundamental role in decreasing the risk of falls and fractures ${ }^{2,3}$. In addition to musculoskeletal changes, cardiovascular changes must be targeted in strategies for this age group, since they are responsible for many deaths and hospitalizations ${ }^{1}$.

Regular low-intensity exercise improves autonomic cardiovascular control by decreasing sympathetic tone and bradycardia at rest. These changes counter decreases in cardiac output and blood pressure (BP), as well as improve baroreflex sensitivity during BP variation ${ }^{4}$. Blood pressure variability (BPV) analysis has shown that the antihypertensive effects of physical training on mild hypertensive subjects are associated with readjustment of the damaged cardiovascular autonomic system in this population ${ }^{5}$.

However, some individuals cannot tolerate exercise because they present a weakened physical state. In such cases, functional electrical stimulation (FES) training may serve as an alternative to conventional training ${ }^{6}$ since it shows beneficial effects similar to physical exercises ${ }^{7}$. FES has been shown to affect muscle plasticity by increasing the diameter of muscle fibers and the proportion of type I fibers due to its activation of specific motoneurons ${ }^{6,7}$.

A meta-analysis by our group has demonstrated the effectiveness of FES intervention in populations with severe cardiovascular disease in that its use in patients with heart failure (HF) resulted in increased maximum oxygen consumption $\left(\mathrm{VO}_{2}\right)$ and distance walked in the 6-minute walk test $(6 \mathrm{MWT})^{8}$.

It is necessary to study the possible cardiovascular and functional implications involved in the use of FES. Thus, the aim of this study was to verify the effects of FES training on the functional capacity and BPV of a centenarian woman.

\section{Methods : :}

\section{Patient}

A centenarian woman (101 years old, weighing $42 \mathrm{~kg}$ and $152 \mathrm{~cm}$ in height) without previous disease or current medication use was assessed.
The study was approved by the Ethics Committee of the Instituto de Cardiologia do Rio Grande do Sul/Fundação Universidade de Cardiologia (IC/FUC), Porto Alegre, Brazil ( $n^{\circ}$. 4327/09). The consent form was signed by a person responsible for the participant.

\section{Assessments}

\section{Six-minute walk test}

The 6MWT used to assess functional capacity followed the guidelines proposed by the American Thoracic Society ${ }^{9}$.

\section{Sit-and-stand test}

In order to assess the proximal strength of the patient's lower limbs, the sit-and-stand test (STST) was performed as follows: with the patient sitting in a chair, her feet apart and flat on the floor and her arms crossed against her chest, she was encouraged to get up and return to a seated position as many times as possible in $30 \mathrm{~s}$. BP, heart rate (HR), respiratory rate and oxygen saturation $\left(\mathrm{SO}_{2}\right)$ were monitored before and after the test.

\section{Assessment of the sympathetic and parasympathetic systems}

The sympathetic and parasympathetic systems were assessed by means of the BP signal, which was obtained in a continuous and noninvasive way by a sensor placed on the middle finger that had been set to a sampling rate of $1000 \mathrm{~Hz}$ per channel. The signal was captured by FINAPRES (Ohmeda 2300, Monitoring Systems, Englewood, CO, USA). The signal was recorded at rest in the supine position after a $30 \mathrm{~min}$ signal stabilization period. The BPV was analyzed in the frequency domain using an autoregressive model and stationary sequences of 200 beats. Spectral power was obtained in the low frequency (LF: $0.03-0.15 \mathrm{~Hz}$ ) and high frequency (HF: $0.15-0.4 \mathrm{~Hz}$ ) ranges.

\section{Biochemical assessment}

Blood glucose, glycated hemoglobin, urea, creatinine, uric acid, total cholesterol, HDL cholesterol, cholesterol/HDL cholesterol, triglycerides, glutamic-oxaloacetic transaminase, glutamic-pyruvic transaminase, total and direct bilirubin, alkaline phosphatase and C-reactive protein (CRP) were analyzed.

\section{Quadriceps perimetry}

Quadriceps perimetry was measured every $5 \mathrm{~cm}$, starting from the top edge of the patella in the proximal direction. Thus, 
measurements of 5, 10, 15 and $20 \mathrm{~cm}$ were performed in both lower limbs.

\section{Training Protocol}

Three weekly sessions of FES training with a functional electrical stimulation device (Physiological Electricalstimulator - LYNX - FMUSP, São Paulo, Brazil) were conducted in the participant's home for a period of 12 weeks.

Table 1. Anthropometric and biochemical parameters before and after FES training.

\begin{tabular}{lcc} 
& Before FES & After FES \\
\hline Body Mass (kg) & 42 & 44 \\
\hline Height (m) & 1.52 & 1.52 \\
\hline BMI (kg/m²) & 18.2 & 19 \\
\hline RSP $20 \mathrm{~cm}(\mathrm{~cm})$ & 47 & 49 \\
\hline LSP $20 \mathrm{~cm}(\mathrm{~cm})$ & 47 & 50 \\
\hline Cholesterol (mg/dL) & 132 & 131 \\
\hline HDL Cholesterol (mg/dL) & 29 & 34 \\
\hline Cholesterol/HDL Cholesterol & 4.6 & 3.9 \\
\hline Fasting Glucose (mg/dL) & 89 & 91 \\
\hline HbA 1 (\%) & 5.6 & 5.9 \\
\hline Urea (mg/dL) & 36 & 45 \\
\hline Creatinine (mg/dL) & 1.1 & 1.3 \\
\hline Uric acid (mg/dL) & 3.7 & 3.4 \\
\hline Triglycerides (mg/dL) & 115 & 132 \\
\hline AST (U/L) & 8 & 8 \\
\hline GPT (U/L) & 5 & 4 \\
\hline Direct Bilirubin (mg/dL) & 0.14 & 0.06 \\
\hline Total Bilirubin (mg/dL) & 0.54 & 0.57 \\
\hline Alkaline phosphatase (U/L) & 64 & 51 \\
\hline CRP (mg/dL) & 0.28 & 0.04 \\
\hline
\end{tabular}

FES=Functional Electrical Stimulation; BMI=Body Mass Index; RSP=Right Suprepatellar Perimetry; LSP=Left Suprapatellar Perimetry; HDL=High-Density Lipoprotein; $\mathrm{HbA}^{1 \mathrm{c}}=\mathrm{Glycated}$ Hemoglobin; AST=Aspartate Aminotransferase; GPT=Glutamic Pyruvic Transaminase; CRP=C-Reactive Protein.

Table 2. Autonomic and hemodynamic parameters before and after FES training.

\begin{tabular}{lcc}
\hline & Before FES & After FES \\
\hline SBP $(\mathrm{mmHg})$ & 128.41 & 120.61 \\
\hline SAPV $\left(\mathrm{mmHg}^{2}\right)$ & 21.38 & 9.59 \\
\hline DBP $(\mathrm{mmHg})$ & 54.64 & 50.70 \\
\hline DAPV $\left(\mathrm{mmHg}^{2}\right)$ & 3.47 & 1.17 \\
\hline MAP $(\mathrm{mmHg})$ & 74.11 & 70.51 \\
\hline MAPV $\left(\mathrm{mmHg}^{2}\right)$ & 8.94 & 2.93 \\
\hline SAPV spectral analysis & & \\
\hline LF frequency peak $(\mathrm{Hz})$ & 0.12 & 0.12 \\
\hline LF power $\left(\mathrm{mmHg}^{2}\right)$ & 8.54 & 4.21 \\
\hline HF frequency peak $(\mathrm{Hz})$ & 0.26 & 0.31 \\
\hline HF power $\left(\mathrm{mmHg}^{2}\right)$ & 4.25 & 4.03 \\
\hline
\end{tabular}

FES=Functional Electrical Stimulation; SBP=Systolic Blood Pressure; SAPV=Ssystolic Arterial Pressure Variability; DBP=Diastolic Blood Pressure; DAPV=Diastolic Arterial Pressure Variability; MAP=Mean Blood Pressure; MAPV=Mean Arterial Pressure Variability; LF=Low-Frequency component of SAPV; HF=High-Frequency component of SAPV.
FES was applied at a frequency of $20 \mathrm{~Hz}$ with a $0.5 \mathrm{~ms}$ pulse width, a $5 \mathrm{~s}$ contraction time, a $10 \mathrm{~s}$ rest time and at the maximum tolerable intensity for $40 \mathrm{~min} / \mathrm{session}$ or until muscle fatigue, which was defined as the participant's inability to perform a full knee extension, even with the device set to higher intensity. The load imposed on the patient progressed $0.5 \mathrm{~kg}$ each week (overload principle) during the training period, such that at the 12th week $5.5 \mathrm{~kg}$ of weight was lifted in each lower limb due to FES alone. Self-adhesive electrodes (Spes - 50 x 90 mm, Italy) were placed on the inguinal region and on the vastus medialis and vastus lateralis of the femoral quadriceps of both thighs, which caused alternating contractions between the lower limbs to full extension of knees, placed at $60^{\circ}$ of flexion.

\section{Results $: \because$.}

After 12 weeks of FES training, there were changes in anthropometric variables such as body mass, body mass index (BMI) and quadriceps perimetry at $20 \mathrm{~cm}$. With regard to biochemical variables, there was a $17 \%$ increase in HDL cholesterol $(\mathrm{mg} / \mathrm{dL})$ and an $85 \%$ decrease in CRP $(\mathrm{mg} / \mathrm{dL})$. The other variables remained similar to baseline (Table 1).

Functional capacity increased $70 \%$ according to the distance walked in the 6MWT (64 vs. $109 \mathrm{~m}$ ) and there was a 300\% increase in STST performance (3 vs. 9 repetitions).

There were decreases of approximately $8 \mathrm{~mm} \mathrm{Hg}$ in systolic blood pressure (SBP) and of $4 \mathrm{mmHg}$ in diastolic blood pressure (DBP) and mean arterial pressure (MBP) after training. In addition, there was a decrease in SBP, DBP and MBP variability and in the absolute value of the LF component of $\mathrm{BPV}$, indicating a decrease in vascular sympathetic modulation (Table 2).

\section{Discussion $: \because$.}

This is the first case report in the literature regarding the use of FES in an individual over 100 years old. The results demonstrate an increase in functional capacity and muscle strength, decreased resting blood pressure values, reduced vascular sympathetic activation and a decrease in inflammatory markers.

Aging leads to decreased muscle strength as well as cardiovascular changes. FES training may be a non-pharmacological and non-invasive alternative means of preventing or treating these changes ${ }^{2-4}$.

It has already been shown that the use of FES in patients with HF improves functional capacity, muscle strength and inflammatory markers ${ }^{6,8}$. The possible mechanisms involved are increases in the number of muscle fibers, enzyme activity and 
energy expenditure, which, although not evaluated in our study (i.e., being limitations) have probably occurred and would justify the improvement observed in the studied variables. Other factors that would support the occurrence of an increase in muscle fibers were the observed increases in strength and increase in perimetry values of lower limbs.

There was significant decrease in the values of DBP, MBP and, in particular, of the SBP, which had a decline of $8 \mathrm{mmHg}$, shifting its value of pressure for a condition considered to be ideal. These values are related to lower cardiovascular risk and, consequently, higher survival of population ${ }^{10}$. Another aspect that is related to the improvement in the cardiovascular system can be observed by the analysis of BPV, which showed decrease in systolic, diastolic and mean BPV considered important indices in the assessment of cardiovascular autonomic control. Another important indicator that shows a direct relationship with these results is the decrease of the LF component of SBPV, associated with vascular sympathetic modulation, which may, partly, explains the decrease in blood pressure values.
Studies show that conventional exercise provides decrease of sympathetic vascular modulation ${ }^{4}$, however there was still no study demonstrating this effect with FES. The hemodynamic and autonomic changes observed suggest a potential benefit provided by the FES, very similar to that achieved with conventional exercise.

Thus, it was concluded that FES training promotes increase of functional capacity, muscle strength and improvement of the autonomic control in a centenarian woman. Further studies with larger number of individuals in this age group are required, allowing the formation of evidence about the benefits of FES in this population and providing the widespread use of this physical therapy tool as an alternative in the prevention or treatment of disorders related to aging.

\section{Acknowledgments : :}

To the Conselho Nacional de Desenvolvimento Cientifico e Tecnológico (CNPq).

\section{References : :}

1. Oliveira J, Albuquerque F, Lins I. Projeção da população do Brasil por sexo e idade para 0 período 1980-2050-Revisão 2004: Metodologia e Resultados. Diretoria de Pesquisas-DPE, Coordenação de População e Indicadores Sociais-COPIS2004.

2. Suominen H. Muscle training for bone strength. Aging Clin Exp Res. 2006;18(2):85-93

3. Seguin R, Nelson ME. The benefits of strength training for older adults. Am J Prev Med. 2003;25(3 Suppl 2):141-9.

4. Deley G, Picard G, Taylor J. Arterial baroreflex control of cardiac vagal outflow in older individuals can be enhanced by aerobic exercise training. Hypertension. 2009;53(5): 826-32.

5. Izdebska E, Cybulska I, Izdebskir J, Makowiecka-Ciesla M, Trzebski A. Effects of moderate physical training on blood pressure variability and hemodynamic pattern in mildly hypertensive subjects. J Physiol Pharmacol. 2004;55(4):713-24.

6. Karavidas A, Parissis JT, Matzaraki V, Arapi S, Varounis C, Ikonomidis I, et al. Functional electrical stimulation is more effective in severe symptomatic heart failure patients and improves their adherence to rehabilitation programs. J Card Fail. 2010;16(3):244-9.

7. Harris S, LeMaitre JP, Mackenzie G, Fox KAA, Denvir MA. A randomised study of homebased electrical stimulation of the legs and conventional bicycle exercise training for patients with chronic heart failure. Eur Heart J. 2003;24(9):871-8.

8. Sbruzzi G, Ribeiro RA, Schaan BD, Signori LU, Silva AM, Irigoyen MC, et al. Functional electrical stimulation in the treatment of patients with chronic heart failure: a meta-analysis of randomized controlled trials. Eur J Cardiovasc Prev Rehabil. 2010;17(3):254-60.

9. ATS Committee on Proficiency Standards for Clinical Pulmonary Function Laboratories. ATS statement: guidelines for the six-minute walk test. Am J Respir Crit Care Med. 2002;166(1):111-7.

10. Mancia G, Laurent S, Agabiti-Rosei E, Ambrosioni E, Burnier M, Caulfield MJ, et al Reappraisal of European guidelines on hypertension management: a European Society of Hypertension Task Force document. J Hypertens. 2009;27(11):2121-58. 